\title{
Extracellular matrix regulates human airway smooth muscle cell migration
}

\author{
K. Parameswaran, K. Radford, J. Zuo, L.J. Janssen, P.M. O’Byrne, P.G. Cox
}

Extracellular matrix regulates human airway smooth muscle cell migration. K. Parameswaran, K. Radford, J. Zuo, L.J. Janssen, P.M.O'Byrne, P.G. Cox. (C) ERS Journals Ltd 2004.

ABSTRACT: Extracellular matrix proteins regulate the survival and proliferation of smooth muscle cells. Their effect on airway smooth muscle cell migration is not known.

Their role in leukotriene-primed $\left(0.1 \mu \mathrm{M}\right.$ leukotriene $\left.\mathbf{E}_{4}\right)$ chemotaxis of cultured human airway smooth muscle cells towards platelet-derived growth factor BB $\left(1 \mathrm{ng} \cdot \mathrm{mL}^{-1}\right)$ was investigated.

Migration of cells was greater on membranes coated with collagens III and V and fibronectin compared to collagen I, elastin and laminin (all $\left.10 \mu \mathrm{g} \cdot \mathrm{mL}^{-1}\right)$. Concentrationdependent promotion of migration was observed on collagen $I\left(1,000>10 \mu \mathrm{g} \cdot \mathrm{mL}^{-1}\right)$, which was associated with increased phosphorylation of Src kinase. This was not observed on laminin or elastin. The role of Src kinase was further confirmed by demonstrating that its inhibitor, PP1 analogue $(1 \mu M)$, inhibited chemotaxis. Collagen I itself was not a chemoattractant; however, haptokinesis was observed when cells were primed with leukotriene $\mathbf{E}_{\mathbf{4}}$, and haptotaxis when cells were primed with platelet-derived growth factor. The priming effect of leukotrienes on chemotaxis was not elicited by promoting adhesion, increasing surface expression of $\beta_{1}, \alpha_{v}$ and $\alpha_{5}$ integrin, or Src kinase phosphorylation.

These experiments demonstrate that the extracellular matrix, along with growth factors and cysteinyl leukotrienes, can regulate human airway smooth muscle cell migration. This may be relevant in the remodelling process in chronic airway diseases, such as asthma.

Eur Respir J 2004; 24: 545-551.
Asthma Research Group, Firestone Institute for Respiratory Health, St. Joseph's Healthcare, and Dept of Medicine, McMaster University, Hamilton, Canada.

Correspondence: P.G. Cox, Firestone Institute for Respiratory Health, St. Joseph's Healthcare, 50 Charlton Avenue East, Hamilton, Ontario, L8N 4A6, Canada.

Fax: 19055216132

E-mail: coxp@mcmaster.ca

Keywords: Chemotaxis

cysteinyl leukotrienes

extracellular matrix

human airway smooth muscle

integrins

Src kinase

Received: October 82003

Accepted after revision: May 42004

This study was supported by a Canadian Allergy, Asthma and Immunology Foundation (Ottawa, Canada) grant. K. Parameswaran is a postdoctoral fellow of the Canadian Institutes of Health Research (Ottawa, Canada).
Smooth muscle and extracellular matrix proteins are important components of the lamina reticularis in the remodelled airway mucosa of patients with asthma [1]. It is generally believed that inflammatory cells, such as eosinophils, mast cells, macrophages and lymphocytes, which infiltrate the airway mucosa, initiate the remodelling process. They interact with resident structural cells and lay down fibronectin, elastin, laminin and other proteins that constitute the extracellular matrix [2, 3]. However, smooth muscle cells, which are seen in great numbers and size immediately beneath the epithelium in asthma, are not normally resident in this area, but in the area below the submucosa [4]. Little is known about the processes that regulate the accumulation of airway smooth muscle in the part of the airway immediately beneath the mucosal epithelial cells. These cells, like other inflammatory cells, are capable of directional migration $[5,6]$ and have been demonstrated to migrate close to the submucosa in the airways of asthmatic subjects following allergen inhalation [7, 8].

Since extracellular matrix proteins are able to regulate the survival [9], proliferation [10] and cytoskeletal reorganisation [9] of airway smooth muscle cells, and the migration of vascular smooth muscle cells [11], their role in the regulation of human airway smooth muscle cell adhesion and migration was investigated. It was hypothesised that the matrix proteins

For editorial comments see page 515. that are deposited in greater quantities in asthmatic airways, i.e. collagens I, III and V, fibronectin and laminin, would support migration more than matrix proteins such as elastin and collagen IV, which are less conspicuous in asthmatic airways. Since it had previously been demonstrated that cysteinyl leukotrienes (LTs) augment the chemotaxis of human airway smooth muscle cells [5], it was investigated whether they also modulate the effect of extracellular matrix proteins. The precise signal transduction mechanisms involved in the chemotaxis of airway smooth muscle cells are not clear [12]. Adhesion to a matrix surface via integrins is an essential first step. The Rho/Rho kinase pathways modulate reorganisation of the actin cytoskeleton. Directional migration is likely to involve the phosphatidylinositol3'-kinase (PI3K) and mitogen-activated protein kinase (MAPK) pathways. Since integrins activate Src kinase (SrcK) through the focal adhesion kinase complex, which, in turn, can activate the PI3K and MAPK pathways [13], it was hypothesised that the matrix proteins might facilitate chemotaxis of smooth muscle cells by activation of SrcK.

Therefore, the specific questions addressed were as follows: 1) do the different matrix proteins support migration differently?; 2) is this effect concentration-dependent?; 3) are matrix proteins chemoattractants?; 4) do LTs promote adhesion just as they augment migration?; and 5) are integrins, $\mathrm{PI} 3 \mathrm{~K}$ and SrcK involved in adhesion and migration? 


\section{Methods}

\section{Smooth muscle culture}

Human lungs that were resected at St. Joseph's Healthcare (Hamilton, Canada) were obtained after obtaining approval from the Institutional Review Board and the consent of the patients undergoing resection. Smooth muscle tissue was isolated from disease-free areas of the bronchi. Airway smooth muscle cells were grown to confluence in Roswell Park Memorial Institute (RPMI) 1640 culture medium containing 10\% FCS and penicillin/streptomycin (100 units $\cdot \mathrm{mL}^{-1} / 100 \mu \mathrm{g} \cdot \mathrm{mL}^{-1}$ ) (all from Invitrogen Canada Inc., Burlington, Canada). The confluent cell growth exhibited the typical "hill and valley" appearance using light microscopy, and also showed caveolae and gap junctions using electron microscopy (data not shown). The cells were passaged between two and five times.

\section{Migration assay}

Confluent cells were maintained in growth-factor-free medium for $24 \mathrm{~h}$ prior to experiments. The cells were then harvested using trypsin (Invitrogen Canada Inc.; 0.05\%), counted, centrifuged and resuspended at a density of $8.0 \times$ $10^{5}$ cells $\cdot \mathrm{mL}^{-1}$ in RPMI 1640 medium containing $0.3 \%$ bovine serum albumin (BSA; Invitrogen Canada Inc.) (BSA-RPMI). The cells $(100 \mu \mathrm{L})$ were then plated on the upper side of a matrix-treated polycarbonate membrane $(8.0-\mu \mathrm{M}$ pore) separating two chambers of a $6.5-\mathrm{mm}$ Transwell culture plate (BSA-RPMI was added to both chambers $30 \mathrm{~min}$ before treatments). The chemoattractants $(600 \mu \mathrm{L})$ were added to the lower wells. After $5 \mathrm{~h}$, the membranes were peeled off and the cells on the upper face of the membranes were scraped using a cotton swab. Cells that migrated to the lower face of the membrane were fixed in $3.7 \%$ formaldehyde and stained with Diff-Quik Wright Giemsa Solution (VWR International, Mississauga, Canada). The number of migrated cells on the lower face of the filter were counted at 20 -fold magnification in four random fields (Olympus BX40 microscope; Olympus, Tokyo, Japan; Sony 3CCD Power HAD video camera; Sony, Tokyo, Japan; and Northern Eclipse software; Empix Imaging, Mississauga, Canada). Assays were performed in duplicate using cells from six different resected lung tissue samples.

\section{Chemotaxis/chemokinesis}

The chemotactic response (haptotaxis) of airway smooth muscle cells was studied using platelet-derived growth factor (PDGF) BB (Invitrogen Canada Inc.; $1 \mathrm{ng} \cdot \mathrm{mL}^{-1}$ ) (based on previous experiments [5]) or collagen I (Calbiochem, San Diego, CA, USA; $1,000 \mu \mathrm{g} \cdot \mathrm{mL}^{-1}$ ) as chemoattractants in the lower well. Haptokinesis towards collagen I was studied by adding $1,000 \mu \mathrm{g} \cdot \mathrm{mL}^{-1}$ collagen to both the inner and outer wells. The regulatory effect of matrix proteins was studied by coating the polycarbonate membrane of the Transwell insert with the various matrix proteins (Calbiochem; $10 \mu \mathrm{g} \cdot \mathrm{mL}^{-1}$ each). The membrane was treated overnight with the matrix solutions, which were then aspirated, and the chambers dried for $4 \mathrm{~h}$ in a laminar flow hood. The inserts were washed thoroughly with deionised water before using them for the experiments. In order to study whether the regulatory effect of the matrix proteins was concentration-dependent, the membranes were coated with 10,100 and $1,000 \mu \mathrm{g} \cdot \mathrm{mL}^{-1}$ collagen I, human elastin (Elastin Products Inc., Owensville, MO, USA) and laminin (Calbiochem) solution. The priming effect of $\mathrm{LTE}_{4}$ (Cayman Chemicals, Ann Arbor, MI, USA; $\left.1 \times 10^{-7} \mathrm{M}\right)$ or PDGF $\left(1 \mathrm{ng} \cdot \mathrm{mL}^{-1}\right)$ was studied by adding them to the smooth muscle cells $30 \mathrm{~min}$ before the haptotaxis experiment using collagen I.

\section{Adhesion experiments}

Smooth muscle cells were harvested from the $75-\mathrm{cm}^{2}$ plates, washed in phosphate-buffered saline (PBS; Invitrogen Canada Inc.) and transferred at a seeding density of 20,000 cells $\cdot$ well $^{-1}$ in RPMI 1640 medium containing $10 \%$ FCS into 24-well plates precoated with collagen I (at concentrations of $0.1,1,10,100$ and $1,000 \mu \mathrm{g} \cdot \mathrm{mL}^{-1}$ ). At 30, 60 and $120 \mathrm{~min}$, the plates were removed from the incubator and the overlying medium removed by gentle aspiration. After washing in $0.5 \mathrm{~mL}$ PBS, the remaining adherent cells were removed using trypsin/ethylenediamine tetra-acetic acid (EDTA; $0.53 \mathrm{mM}$ ) and counted using a haemocytometer. The priming effect of LT was studied by adding $\operatorname{LTE}_{4}(0.1 \mu \mathrm{M})$ to the smooth muscle cells 30 min before the experiment.

\section{Signal transduction pathways}

The integrin-mediated signalling of airway smooth muscle cell adhesion and migration was studied using specific pharmacological antagonists of PI3K and SrcK. The PI3K inhibitor LY294002 (Sigma, Oakville, Canada; $50 \mu \mathrm{M}$ ) and the SrcK inhibitor PP1 analogue (4-amino-1-tert-butyl-3-(1naphthyl) pyrazolo[3,4-d] pyrimidine; Calbiochem; 0.1, 1.0, 10 and $30 \mu \mathrm{M}$ ) were added to the smooth muscles cells $30 \mathrm{~min}$ prior to the adhesion and migration assays and remained in contact with the cells for the entire duration of the study. In order to study the effect of integrins on airway smooth muscle adhesion to matrix, blocking antibodies directed against $\beta_{1}$, $\alpha_{\mathrm{v}}$ and $\alpha_{5}$ integrin $(50 \mu \mathrm{M}$ each) were added to the smooth muscle cells $30 \mathrm{~min}$ prior to seeding on culture plates.

\section{Flow cytometry}

The effect of pretreatment with $\operatorname{LTE}_{4}(0.1 \mu \mathrm{M})$ for $30 \mathrm{~min}$ on integrin expression by airway smooth muscle cells was studied using flow cytometry. Treatment with recombinant human tumour necrosis factor- $\alpha$ (TNF- $\alpha$; PeproTech Canada Inc., Ottawa, Canada; $100 \mathrm{U} \cdot \mathrm{mL}^{-1}$ for $24 \mathrm{~h}$ ) was used as a positive control. Cells were serum-starved for $24 \mathrm{~h}$, trypsinised (exposure kept as short as possible, i.e. $30 \mathrm{~s}$ ), washed in $1 \%$ PBS containing $0.5 \%$ BSA and then incubated with $2 \mu \mathrm{g} \cdot 10^{5}$ cells $^{-1}$ primary antibody directed against $\beta_{1}, \alpha_{\mathrm{v}}$ and $\alpha_{5}$ integrin (Beckman Coulter Canada Inc., Mississauga, Canada) for $30 \mathrm{~min}$ in the dark at room temperature. After washing with $1 \%$ PBS containing $0.5 \%$ BSA, cells were incubated with $2 \mu \mathrm{g} \cdot 10^{5}$ cells $^{-1}$ secondary antibody for another $30 \mathrm{~min}$ before two further washes. Samples were suspended in fluorescence-activated cell sorting fix and acquired and analysed using a FACScan flow cytometer equipped with an argon ion laser and PClysis software (both Becton Dickinson Instrument Systems, Mississauga, Canada).

\section{Sodium dodecylsulphate-polyacrylamide gel electrophoresis} and Western blotting

Airway smooth muscle cells, starved for $24 \mathrm{~h}$ in serum-free medium, were seeded on to plates coated with different 
concentrations of various matrix proteins. After $2 \mathrm{~h}$, the cells were lifted with trypsin (30 s), rinsed with ice-cold PBS, lysed with $1 \mathrm{~mL}$ lysis buffer $(50 \mathrm{mM}$ tris(hydroxymethyl)aminomethane (Tris), $150 \mathrm{mM} \mathrm{NaCl}, 10 \%$ glycerol, $1 \%$ Triton $\mathrm{X}-100,5 \mathrm{mM}$ EDTA, $100 \mu \mathrm{M}$ sodium orthovanadate, $1 \mathrm{mM}$ $\beta$-glycerophosphate, $1 \mathrm{mM} \mathrm{NaF}, 15 \mathrm{U} \cdot \mathrm{mL}^{-1}$ aprotinin) and clarified by centrifugation. Protein concentration was determined using the Bradford method, and equal amounts of protein $(20 \mu \mathrm{g})$ were resolved using 10\% sodium dodecylsulphatepolyacrylamide gel electrophoresis (Bio-Rad, Mississauga, Canada), transferred to $0.22-\mu \mathrm{M}$-pore nitrocellulose filters $(<12.6 \%$ nitrogen content) and probed with a monoclonal antibody that recognises activated $\mathrm{Src}\left(\mathrm{pY}^{418}\right.$ (rabbit polyclonal anti-phospho-Src); BioSource International, Camarillo, CA, USA). Specific proteins were recognised using a secondary antibody conjugated to horseradish peroxidase and enhanced chemiluminescence (Amersham Canada, Oakville, Canada).

\section{Statistical analysis}

Statistical analysis was performed using the repeatedmeasures analysis of variance test, using the different time points or experimental conditions as within-subject factors. The source of significant variation was identified by predefined contrasts. A p-value of $<0.05$ was considered significant.

\section{Results}

\section{Effect of extracellular matrix on migration}

Type of matrix coating on migrating surface. There were significant differences in the number of smooth muscle cells migrating towards PDGF across membranes coated with the various matrix proteins. At a concentration of $10 \mu \mathrm{g} \cdot \mathrm{mL}^{-1}$, migration was maximal on collagens III and V and fibronectin, lesser on laminin and absent on collagen I and elastin $(\mathrm{p}<0.05)$ (fig. 1).

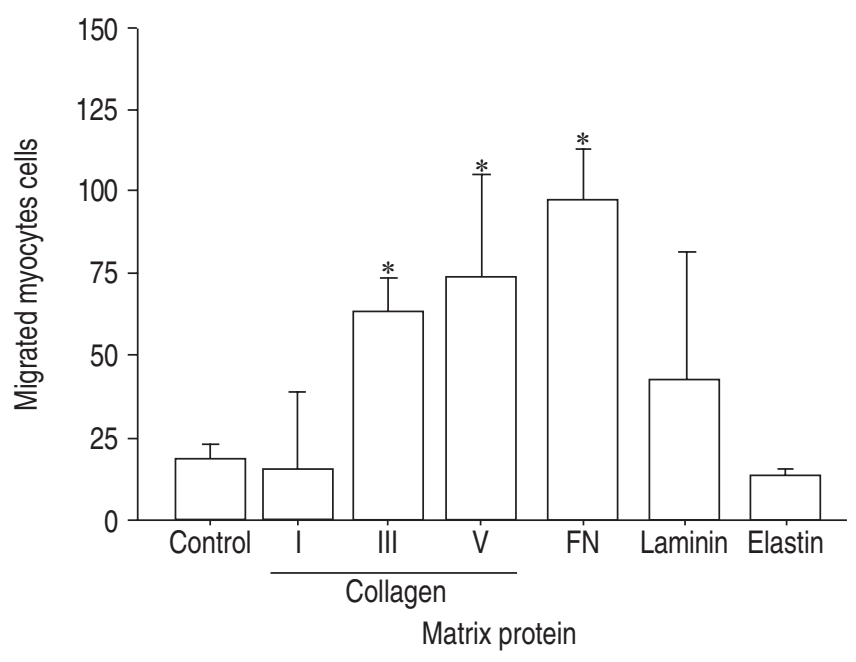

Fig. 1.-Migration of smooth muscle cells on surfaces coated with various matrix proteins. At a concentration of $10 \mu \mathrm{g} \cdot \mathrm{mL}^{-1}$, fibronectin (FN) and collagens III and V supported migration compared to control. Data are presented as mean \pm SD $(n=4$ duplicate experiments). *: $\mathrm{p}<0.05$ versus control.
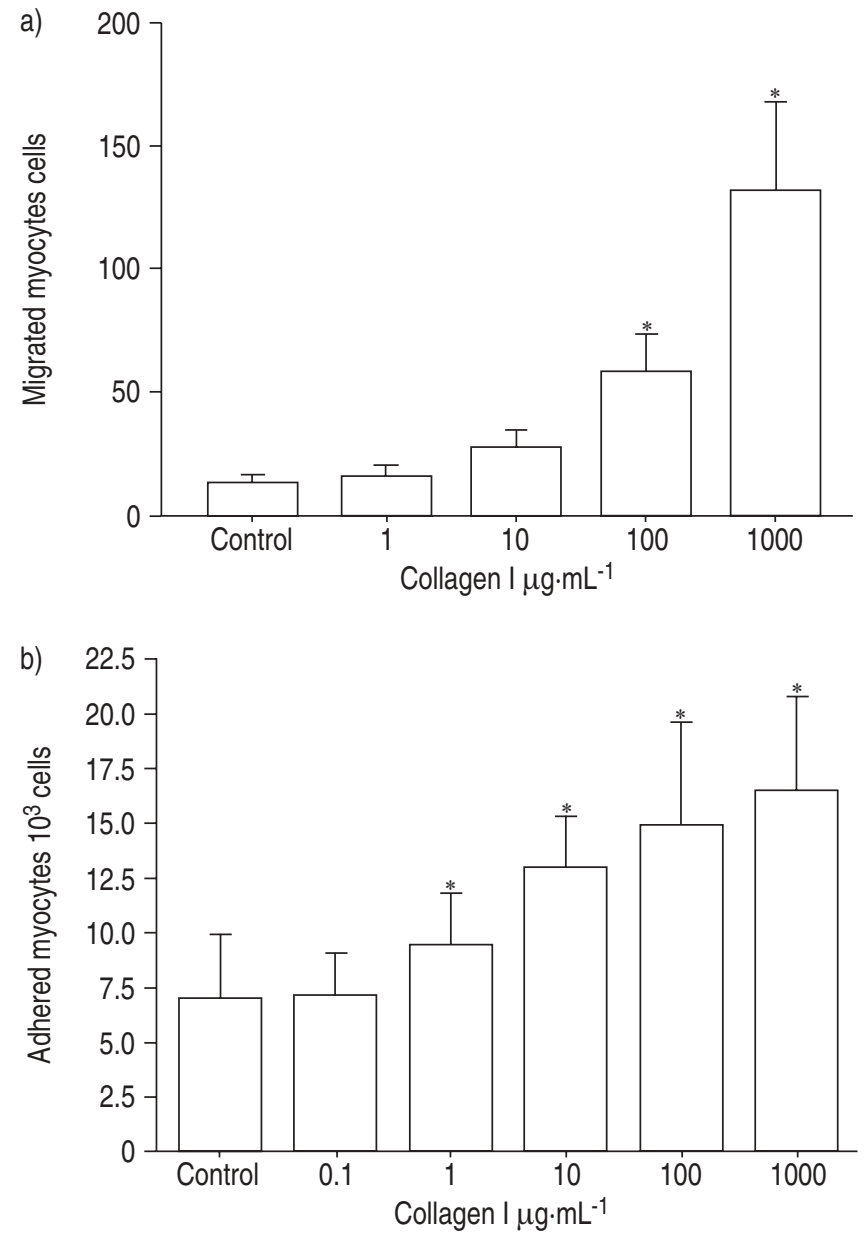

Fig. 2. - Effect of concentration of collagen I coating on: a) migration; and b) adhesion. A concentration-dependent response is observed, with $\geqslant 100 \mu \mathrm{g} \cdot \mathrm{mL}^{-1}$ collagen being required for migration towards platelet-derived growth factor, and $\geqslant 10 \mu \mathrm{g} \cdot \mathrm{mL}^{-1}$ for adhesion. Data are presented as mean \pm SD ( $\mathrm{n}=3$ duplicate experiments). *: $\mathrm{p}<0.05$ versus control.

Concentration of matrix coating on migrating surface. Chemotaxis of smooth muscle cells towards PDGF did not occur across uncoated membrane. With increasing concentrations of collagen I solution coating the membranes $\left(10,100\right.$ and $\left.1,000 \mu \mathrm{g} \cdot \mathrm{mL}^{-1}\right)$, more smooth muscle cells migrated towards PDGF $(\mathrm{p}<0.05)$ (fig. 2). This was not observed with high concentration $\left(1,000 \mu \mathrm{g} \cdot \mathrm{mL}^{-1}\right)$ of laminin or elastin (data not shown).

Matrix proteins as chemoattractants. Collagen I $\left(1,000 \mu \mathrm{g} \cdot \mathrm{mL}^{-1}\right)$ solution was not a chemoattractant for human airway smooth muscle cells (fig. 3). Pretreatment of smooth muscle cells with PDGF increased haptotaxis and haptokinesis towards collagen I. However, cell migration was significantly less than migration towards PDGF.

Signal transduction. Migration across collagen-coated membrane was inhibited by inhibitors of PI3K $(\mathrm{p}<0.05)$ and $\mathrm{SrcK}(50 \%$ inhibitory concentration (IC50) $1 \mu \mathrm{M})(\mathrm{p}<0.05)$ (fig. 4). The role of $\mathrm{SrcK}$ was further demonstrated by higher levels of phosphorylated SrcK in airway smooth muscle cells seeded on culture plates coated with $1,000 \mu \mathrm{g} \cdot \mathrm{mL}^{-1}$ (concentration that supported chemotaxis) than on those coated with $10 \mu \mathrm{g} \cdot \mathrm{mL}^{-1}$ (concentration that does not support migration) (fig. 5a and b). However, Src phosphorylation was also found in airway smooth 


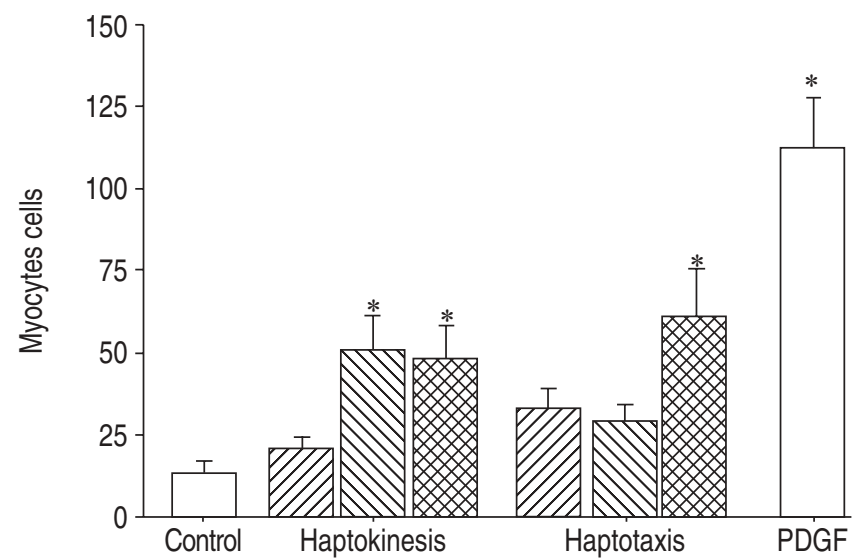

Fig. 3. - Chemoattraction towards collagen I. Collagen I alone ( $\mathbb{C})$ did not induce haptotaxis or haptokinesis. Pre-exposure of cells to leukotriene $(\mathrm{LT}) \mathrm{E}_{4}(\mathbb{\nabla})$ promoted haptokinesis, and pre-exposure to platelet-derived growth factor (PDGF; $)$ promoted both haptotaxis and haptokinesis. However, this response was less than that of chemotaxis towards PDGF. Data are presented as mean \pm SD $(n=4$ duplicate experiments). ${ }^{*}: \mathrm{p}<0.05$ versus control.

muscle cells coated on elastin and laminin, although they did not support migration to the same extent as fibronectin (fig. 5c), suggesting that Src kinase is associated with chemotaxis, but is not the only pathway involved in the process.

\section{Effect of extracellular matrix on adhesion}

Adhesion to collagen I was maximal at $2 \mathrm{~h}$ after seeding. Adhesion was observed at lower concentrations of collagen I than required for migration (fig. 2). Adhesion was inhibited by blocking antibodies directed against the $\alpha_{5}, \alpha_{\mathrm{V}}$ and $\beta_{1}$ subunits of integrin; however, unlike the effect on chemotaxis, adhesion was not inhibited by inhibitors of PI3K and SrcK (fig. 4).

\section{Effect of leukotriene priming on adhesion and migration on different matrices}

Pretreatment (priming) with $\mathrm{LTE}_{4}$ did not increase adhesion to surfaces coated with collagen I, although it augmented the chemotaxis of smooth muscle cells towards PDGF. Consistent with this observation, $\mathrm{LTE}_{4}$ did not increase the intensity and number of integrins $\left(\alpha_{5}, \alpha_{\mathrm{V}}\right.$ and $\left.\beta_{1}\right)$ expressed on the surface of airway smooth muscle cells (fig. 6, table 1). In contrast, TNF- $\alpha$ caused a 1.7 -fold increase in the intensity of $\beta_{1}$ integrin expression. In addition, priming with $\mathrm{LTE}_{4}$ did not overcome the inhibitory effect of antibodies directed against $\alpha_{5}, \alpha_{\mathrm{V}}$ and $\beta_{1}$ integrin on the adhesion of airway smooth muscle cells to collagen I. A priming response on chemotaxis was observed on all the matrix proteins that supported migration. An increase in phosphorylation of Src kinase was not observed in airway smooth muscle cells treated with the concentration of $\mathrm{LTE}_{4}$ that augmented the migratory response to PDGF (fig. 5d).

\section{Discussion}

The present study shows that extracellular matrix proteins can modulate chemotaxis of human airway smooth muscle cells. Chemotaxis is influenced by the type and quantity of matrix proteins present. The effect is partly dependent on PI3K and SrcK. Cysteinyl LTs augment chemotaxis on all the matrix surfaces that facilitate migration; however, they do not
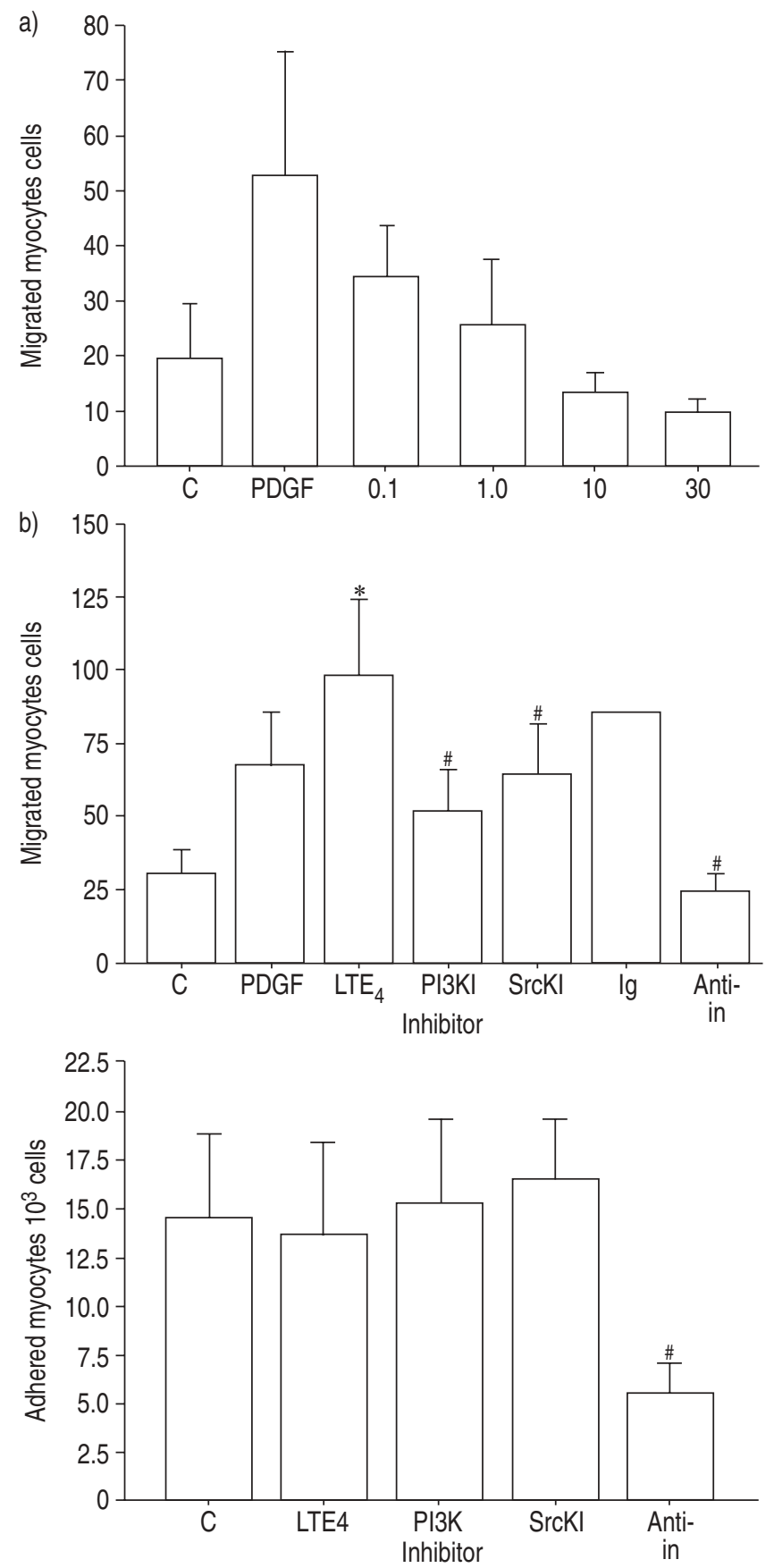

Fig. 4. - Signalling pathways in migration and adhesion on collagen I. a) Effect of PP1 analogue (a pharmacological antagonist of Src kinase) on human airway smooth muscle cell migration on collagen I. $1 \mu \mathrm{M}$ PP1 analogue caused $50 \%$ inhibition of migration towards plateletderived growth factor (PDGF). b, c) Leukotriene (LT) $\mathrm{E}_{4}$-priming increases migration towards PDGF, but does not increase adhesion. Inhibitors of SrcK (SrcKI (PP1 analogue) $1 \mu \mathrm{M}$ ) and PI3K (PI3KI (LY294002) $50 \mu \mathrm{M}$ ) attenuated migration but not adhesion. Blocking antibodies directed against the $\alpha_{5}, \alpha_{\mathrm{V}}$ and $\beta_{1}$ subunits of integrin (IN) (anti-integrins) attenuated both migration and adhesion. The isotype immunoglobulin (Ig) control did not inhibit chemotaxis. Data are presented as mean $\pm S D$ (a) $n=3$ duplicate experiments; b, c) $n=6$ duplicate experiments $(\mathrm{n}=2$ for isotype immunoglobulin control)). $\mathrm{C}$ : control. *: $\mathrm{p}<0.05$ versus control; ${ }^{\#}: \mathrm{p}<0.05$ versus maximum response.

augment adhesion to matrix. These observations are relevant to the remodelling observed in the airways of patients with inflammatory diseases such as asthma. The deposition of 
a)

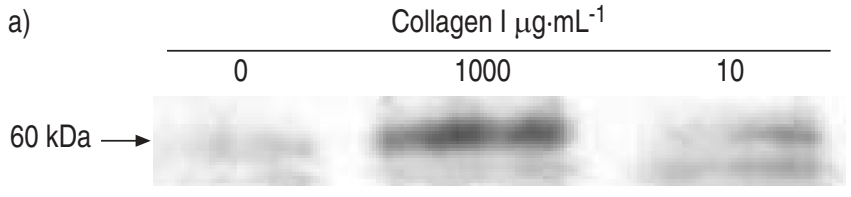

b)
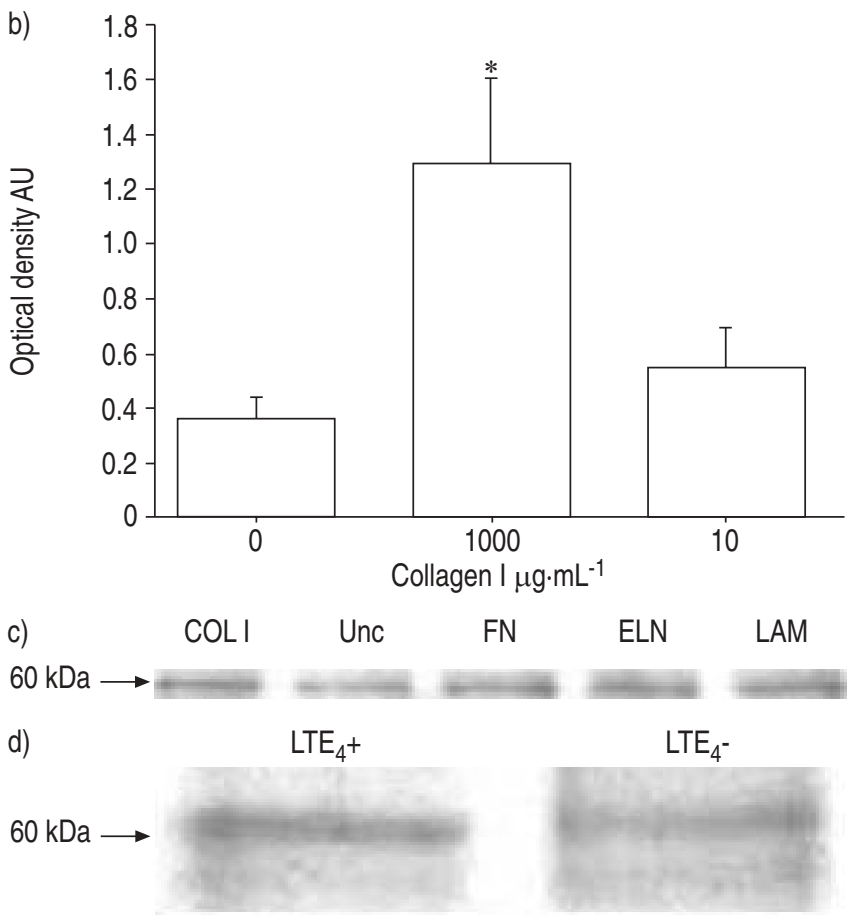

Fig. 5.- Representative Western blots showing expression of activated Src kinase $(60 \mathrm{kDa})$ in airway smooth muscle cells seeded for $2 \mathrm{~h}$ on surfaces coated with: a) varying concentrations of collagen I; and c) various matrix proteins $\left(10 \mu \mathrm{g} \cdot \mathrm{mL}^{-1}\right.$ each); and d) primed with leukotriene (LT) $E_{4}$. b) Optical densities of bands shown in a). a) There is increased phosphorylation of tyrosine residue 418 of Src kinase in smooth muscle cells plated on collagen at a concentration of $1,000 \mu \mathrm{g} \cdot \mathrm{mL}^{-1}$ (supports migration) compared to $10 \mu \mathrm{g} \cdot \mathrm{mL}^{-1}$ (does not support migration). b) The same Src kinase phosphorylation was observed on surfaces that do (fibronectin (FN) and collagen (COL) I) and do not (elastin (ELN) and laminin (LAM)) support migration. c) Increased Src kinase phosphorylation was not observed in airway smooth muscle cells treated with $\mathrm{LTE}_{4}$ for $30 \mathrm{~min}$. Data are presented as mean $\pm S D$ (a, d) $n=4$ experiments; b, c) $n=3$ experiments). AU: arbitrary units; Unc: Uncoated. *: $\mathrm{p}<0.05$ versus control.

matrix in the subepithelial region may of itself promote the migration of airway smooth muscle cells towards the lamina reticularis.

The effect of the extracellular matrix on airway smooth muscle migration was examined for two reasons. First, extracellular matrix proteins, such as collagen, fibronectin, laminin and thrombospondin, regulate migration of vascular smooth muscle cells [11, 14]. Some matrix proteins (e.g. collagens I and IV) promote vascular smooth muscle migration more than others (e.g. laminin) [14]. There is very little information available regarding their regulation of airway smooth muscle cell movement. Secondly, in airway diseases such as asthma, there is excessive accumulation of various extracellular matrix components and smooth muscle cells in the lamina reticularis. The matrix proteins that are commonly observed in the lamina reticularis are collagens I, III and V and fibronectin, and, less frequently, laminin. Elastin and collagen IV are rarely observed [15]. These proteins have different effects on various aspects of smooth muscle function, such as survival, proliferation and actin cytoskeletal reorganisation. For example, fibronectin and

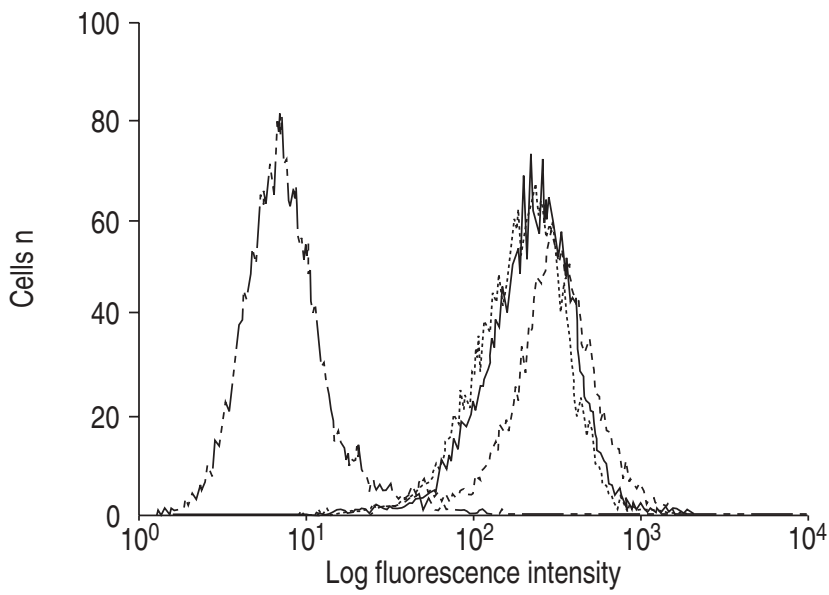

Fig. 6. - Effect of leukotriene (LT) $\mathrm{E}_{4}$ on $\beta_{1}$-integrin expression on airway smooth muscle cells. Human airway smooth muscle cells were stained using monoclonal antibodies directed against the $\beta_{1}$ subunit of integrin and sorted by flow cytometry. $\mathrm{LTE}_{4}$ priming $(\longrightarrow)$ did not increase the intensity of expression compared to non-LTE - $^{-}$ primed cells $(\cdots \cdots)$. Tumour necrosis factor- $\alpha$ (----) increased expression $\sim 1.5$-fold (-..-..-: negative control). Data are presented as means $(\mathrm{n}=3$ duplicate experiments).

Table 1.-Surface expression of integrin subunits on airway smooth muscle cells treated with leukotriene (LT) $\mathrm{E}_{4}$

Integrin Surface expression \% Expression intensity Fluorescence

\begin{tabular}{ccccccc}
\cline { 6 - 7 } & $\mathrm{C}$ & $\mathrm{LTE}_{4}$ & $\mathrm{TNF}-\alpha$ & $\mathrm{C}$ & LTE $_{4}$ & TNF- $\alpha$ \\
\hline$\alpha_{\mathrm{v}}$ & 94 & 91 & 99 & 127 & 110 & 184 \\
$\alpha_{5}$ & 80 & 75 & 98 & 63 & 66 & 128 \\
$\beta_{1}$ & 97 & 92 & 100 & 310 & 219 & 512 \\
\hline
\end{tabular}

Data are presented as means. C: control (not treated with $\mathrm{LTE}_{4}$ ); TNF- $\alpha$ : tumour necrosis factor- $\alpha$ (positive control). $n=3$ separate experiments.

collagen I promote the proliferation of cultured airway smooth muscle cells in a dose-dependent fashion, whereas laminin inhibits growth [10]. When survival of cells was studied, cells plated on a surface coated with elastin survived a shorter time than cells plated on surfaces coated with fibronectin, collagens I and V, laminin and vitronectin [9]. These experiments led to the hypothesis that such a differential effect might also be observed in the ability of matrix proteins to support chemotaxis. Indeed, the morphololgy of smooth muscle cells grown on surfaces coated with fibronectin and laminin show greater polarisation of the actin cytoskeletal system, suggesting that these matrix surfaces may promote greater migration [9].

It was observed that collagen $\mathrm{V}$ and fibronectin supported migration more than collagens I and III and laminin, whereas elastin, which is not usually observed in asthmatic lamina reticularis, had no effect. It was also observed that collagen I, but not laminin or elastin, supports migration in a concentration-dependent manner. The matrix solutions were prepared in order to provide a monomeric coating to the surfaces, as fibrillar matrix may not permit migration [16]. These observations suggest that the type and quantity of matrix deposited in the lamina reticularis may influence the migration of airway smooth muscle cells towards it and their further survival and proliferation, contributing to the increased smooth muscle mass in patients with long-standing asthma. This study also tested whether insoluble collagen can act as a chemoattractant to smooth muscle cells (haptotaxis 
and haptokinesis), similar to the effect of matrix proteins on vascular smooth muscle cells [17] and fibroblasts [18, 19]. Similar to the effects on vascular smooth muscle cells $[14,20]$, it was observed that collagen of itself caused a 2.5-fold increase in haptotaxis (nonsignificant, perhaps because the study was underpowered), which was further increased when cells were pretreated with PDGF. The precise mechanism was not examined, but it is likely that PDGF upregulates integrin expression on airway smooth muscle cells [21], promoting adhesion and downstream signalling. It is also possible that matrix-induced calcium release within airway smooth muscle cells [22] contributes to cell motility.

Some of the signalling pathways involved in the regulation of airway smooth muscle cell migration by matrix proteins were also investigated. Although the signal transduction pathways are not clearly defined, it is suggested that binding of the integrin subunits on the surface of smooth muscle cells to the arginine-glycine-aspartate sequence of amino acids in the matrix can trigger an "outside-inside" signalling event in the smooth muscle. This leads to activation of focal adhesion kinase and the $60-\mathrm{kDa} \mathrm{c}-\mathrm{Src}$ kinase. This leads to a further cascade of phosphorylation, including that of paxillin, PI3K and p38 MAPK, ultimately resulting in actin remodelling and chemotaxis $[23,24]$. Consistent with this, it was observed that blocking antibodies directed against integrin subunits $\beta_{1}, \alpha_{\mathrm{v}}$ and $\alpha_{5}$, which are the integrins most frequently expressed on human airway smooth muscle cells [9], inhibited both adhesion and migration. The contributions of individual integrin subunits were not studied. Pharmacological antagonists of SrcK and PI3K both inhibited chemotaxis, confirming their roles in mediating this activity. Neither antagonist had any effects on adhesion to matrix, similar to observations in vascular smooth muscle [25], suggesting that their effect occurs upstream of integrin matrix assembly. The results may be limited by the lack of specificity of the pharmacological antagonists. For example, PP1 analogue, which has an IC50 of $0.5 \mu \mathrm{M}$ for $\mathrm{SrcK}$ [26], may inhibit stress-activated protein kinases at high doses. It is possible that, at the $1-\mu \mathrm{M}$ concentration used (fig. 4), PP1 analogue may have caused some nonspecific inhibition, particularly of p38 MAPK [26], which is also important in promotion of cell migration. The concentration of LY294002 used $(50 \mu \mathrm{M})$ was five times the reported IC50 in nonhuman cell lines [27]. This high dose was chosen because it has been reported to decrease human vascular smooth muscle migration [28] and airway smooth muscle proliferation [29]. Further evidence for the role of $\mathrm{SrcK}$ in chemotaxis was provided by the demonstration of increased phosphorylation of Src and increased chemotaxis when muscle cells were seeded on surfaces coated with increasing concentrations of collagen I. The role of $\mathrm{SrcK}$ is consistent with previous observations in fibroblasts lacking Src family kinases, in which overexpression of Src promoted tyrosine phosphorylation, cell spreading and migration [30]. It was expected that there would be less Src phosphorylation in smooth muscle cells plated on surfaces that promote less migration. However, the same degree of phosphorylation was observed, again suggesting that SrcK, although important in chemotaxis, is not the only regulator of chemotaxis. A possible alternative mechanism of increasing cell motility and chemokinesis by $\mathrm{Src}$ is via regulation of phosphatidylinositol bisphosphate and intracellular calcium levels [31]. The precise mechanism by which fibronectin promotes more migration than do collagen, laminin and elastin was not studied. This is currently being investigated, specifically the role of SrcK and $\mathrm{PI} 3 \mathrm{~K}$ and their interaction with the laminin/elastin receptors and integrins. Also, SrcK activation was not studied at time points earlier than $2 \mathrm{~h}$ after seeding smooth muscle cells on matrix. This may have influenced the study results.

The ability of cysteinyl LTs to augment chemotaxis of smooth muscle cells towards PDGF had previously been demonstrated [5]. The aim of the present study was to determine whether this was a consequence of increased adhesion or migration. In contrast to the effect on chemotaxis, a priming effect of $\mathrm{LTE}_{4}$ on adhesion was not observed at the same dose that promoted migration. This lack of priming is probably due to $\mathrm{LTE}_{4}$ not increasing the surface expression of integrins that are necessary for adhesion. This was further supported by the observation that priming with $\mathrm{LTE}_{4}$ did not overcome the inhibitory effect of anti-integrin antibodies on adhesion. Since a range of doses of $\mathrm{LTE}_{4}$ over a range of exposure times were not studied, it cannot be concluded that cysteinyl LTs do not activate surface integrins. However, it was observed that priming with LTs increased the haptokinesis engendered by collagen I. Given that cysteinyl LTs can augment growth-factor-stimulated synthesis of proteoglycans such as versican by airway smooth muscle cells [32], and that it can promote haptokinesis towards matrix and chemokinesis towards growth factors, they may play a significant role in airway remodelling.

The interaction between extracellular matrix and airway smooth muscle has important clinical implications in airway diseases such as asthma. They are the most important constituents of a remodelled airway and the least responsive to currently available treatments for asthma [33-35]. It is likely that matrix proteins are synthesised by the resident cells and inflammatory cells infiltrating the airway in patients with asthma. There is now increasing evidence that, once deposited, the matrix, in addition to its mechanical properties, can contribute to airway narrowing by promoting the accumulation of airway smooth muscle cells. It may also decrease the antimitogenic effects of anti-inflammatory treatment such as corticosteroids on airway smooth muscle cells [36]. The present results suggest that it may facilitate more accumulation of airway smooth muscle cells in the lamina propria by chemotaxis. Collectively, these observations suggest that extracellular matrix and airway smooth muscle cell migration should be considered as primary therapeutic targets in patients with chronic asthma.

Acknowledgements. The authors are grateful to W. Gerthoffer, (University of Nevada, Reno, NV, USA) and A. Freyer, (University of Nottingham, Nottingham, UK) for their helpful advice. The authors are also grateful to the Depts of Thoracic Surgery and Pathology (St. Joseph's Healthcare, Hamilton, Canada) for their cooperation in obtaining resected lung specimens.

\section{References}

1. Jeffery PK. Remodeling in asthma and chronic obstructive lung disease. Am J Respir Crit Care Med 2001; 164: S28-S38.

2. Roche WR, Beasley R, Williams JH, Holgate ST. Subepithelial fibrosis in the bronchi of asthmatics. Lancet 1989; 1: $520-524$.

3. Burgess JK, Johnson PRA, Ge Q, et al. Expression of connective tissue growth factor in asthmatic airway smooth muscle cells. Am J Respir Crit Care Med 2003; 167: 71-77.

4. Stephens NL. Airway smooth muscle. Lung 2001; 179: 333373.

5. Parameswaran K, Cox G, Radford K, Janssen LJ, Sehmi R, O'Byrne PM. Cysteinyl leukotrienes promote human airway smooth muscle migration. Am J Respir Crit Care Med 2002; 166: 738-742.

6. Goncharova EA, Billington CK, Irani C, et al. Cyclic AMPmobilizing agents and glucocorticoids modulate human airway smooth muscle cell migration. Am J Respir Cell Mol Biol 2003; 29: 19-27. 
7. Gizycki MJ, Adelroth E, Rogers AV, O'Byrne PM, Jeffery PK. Myofibroblast involvement in the allergen-induced late response in mild atopic asthma. Am J Respir Cell Mol Biol 1997; 16: 664-673.

8. Schmidt M, Sun G, Stacey MA, Mori L, Mattoli S. Identification of circulating fibrocytes as precursors of bronchial myofibroblasts in asthma. J Immunol 2003; 171: 380-389.

9. Freyer AM, Johnson SR, Hall IP. Effects of growth factors and extracellular matrix on survival of human airway smooth muscle cells. Am J Respir Cell Mol Biol 2001; 25: 569-576.

10. Hirst SJ, Twort CHC, Lee TH. Differential effects of extracellular matrix proteins on human airway smooth muscle cell proliferation and phenotype. Am J Respir Cell Mol Biol 2000; 23: 335-344.

11. Schwartz SM. Smooth muscle migration in atherosclerosis and restenosis. J Clin Invest 1997; 100: S87-S89.

12. Madison JM. Migration of airway smooth muscle cells. Am J Respir Cell Mol Biol 2003; 29: 8-11.

13. Aplin AE, Howe A, Alahari SK, Juliano RL. Signal transduction and signal modulation by cell adhesion receptors: the role of integrins, cadherins, immunoglobulincell adhesion molecules, and selectins. Pharmacol Rev 1998; 50: 197-263.

14. Nelson PR, Yamamura S, Kent KC. Extracellular matrix proteins are potent agonists of human smooth muscle cell migration. J Vasc Surg 1996; 24: 25-32.

15. Vignola AM, Mirabella F, Constanzo G, et al. Airway remodeling in asthma. Chest 2003; 123: 417S-422S.

16. Raines EW, Koyama H, Carragher NO. The extracellular matrix dynamically regulates smooth muscle cell responsiveness to PDGF. Ann N Y Acad Sci 2000; 902: 39-51.

17. Stringa E, Knauper V, Murphy G, Gavrilovic J. Collagen degradation and platelet-derived growth factor stimulate the migration of vascular smooth muscle cells. J Cell Sci 2000; 113: 2055-2064.

18. Kondo H, Matsuda R, Yonezawa Y. Platelet-derived growth factor in combination with collagen promotes the migration of human skin fibroblasts into a denuded area of a cell monolayer. Exp Cell Res 1992; 202: 45-51.

19. Kohyama T, Liu X, Wen F-Q, et al. Nerve growth factor stimulates fibronectin-induced fibroblast migration. $J$ Lab Clin Med 2002; 140: 329-335.

20. Nelson PR, Yamamura S, Kent KC. Platelet-derived growth factor and extracellular matrix provide a synergistic stimulus for human vascular smooth muscle cell migration. $J$ Vasc Surg 1997; 26: 104-112.

21. Xu J, Clark RA. Extracellular matrix alters PDGF regulation of fibroblast integrins. J Cell Biol 1996; 132: 239-249.

22. Freyer AM, Fleischmann BK, Hall IP. Characterization of fibronectin-induced calcium signal in human airway myofibroblasts. Am J Respir Crit Care Med 2003; 167: A959.

23. Giancotti FG, Ruoslahti E. Integrin signalling. Science 1999; 285: $1028-1032$.
24. Gerthoffer WT, Gunst S. Focal adhesion and small heat shock proteins in the regulation of actin remodeling and contractility in smooth muscle. J Appl Physiol 2001; 91: 963972.

25. Yamboliev IA, Chen J, Gerthoffer WT. PI 3-kinases and Src kinases regulate spreading and migration of cultured VSMCs. Am J Physiol Cell Physiol 2001; 281: C709-C718.

26. Bain J, McLauchlan H, Elliott M, Cohen P. The specificities of protein kinase inhibitors: an update. Biochem J 2003; 371: 199-204.

27. Davies SP, Reddy H, Caivano M, Cohen P. Specificity and mechanism of action of some commonly used protein kinase inhibitors. Biochem J 2000; 351: 95-105.

28. Kusch A, Tkachuk S, Haller H, et al. Urokinase stimulates human vascular smooth muscle cell migration via a phosphatidylinositol 3-kinase-Tyk2 interaction. J Biol Chem 2000; 275: 39466-39473.

29. Krymskaya VP, Penn RB, Orsini MJ, et al. Phosphatidylinositol 3-kinase mediates mitogen-induced human airway smooth muscle cell proliferation. Am J Physiol 1999; 277: L65-L78.

30. Cary LA, Klinghoffer RA, Sachsenmaier C, Cooper JA. Src catalytic but not scaffolding function is needed for integrinregulated tyrosine phosphorylation, cell migration, and cell spreading. Mol Cell Biol 2002; 22: 2427-2440.

31. Tolloczko B, Turkewitsch P, Choudry S, Bisotto S, Fixman ED, Martin JG. Src modulates serotonin-induced calcium signalling by regulating phosphatidylinositol 4,5 bisphosphate. Am J Physiol Lung Cell Mol Physiol 2002; 282: L1305-L1313.

32. Potter-Perigo S, Baker C, Tsoi C, et al. Regulation of proteoglycan synthesis by leukotriene D4 and epidermal growth factor in bronchial smooth muscle cells. Am J Respir Cell Mol Biol 2004; 30: 101-108.

33. Vanacker NJ, Palmans E, Kips JC, Pauwels RA. Fluticasone inhibits but does not reverse allergen induced structural airway changes. Am J Respir Crit Care Med 2001; 163: 674679.

34. Johnson PRA, Black JL, Carlin S, Ge Q, Underwood PA. The production of extracellular matrix proteins by human passively sensitized airway smooth muscle cells in culture: the effect of beclomethasone. Am J Respir Crit Care Med 2000; 162: 2145-2151.

35. Chakir J, Shannon J, Molet S, et al. Airway remodelingassociated mediators in moderate to severe asthma: effect of steroids on TGF- $\beta$, IL-11, IL-17, and type I and type III collagen expression. J Allergy Clin Immunol 2003; 111: 12931298.

36. Bonacci JV, Harris T, Wilson JW, Stewart AG. Collageninduced resistance to glucocorticoid anti-mitogenic actions: a potential explanation of smooth muscle hyperplasia in the asthmatic remodelled airway. $B r J$ Pharmacol 2003; 138: 1203-1206. 